\title{
Pengaruh Kebijakan Pengalihan Subsidi Bahan Bakar Minyak (Bbm) Untuk Pendidikan Anak-anak di Rumah Tangga Miskin
}

\author{
Adji Pratikto* \\ Atma Jaya Catholic University of Indonesia
}

\begin{abstract}
ABSTRAK
Pendidikan merupakan salah satu aspek terpenting dalam kehidupan seseorang karena akan mempengaruhi kehidupannya ke arah yang lebih baik di masa yang akan datang. Mereka akan memiliki kesempatan untuk mendapatkan pekerjaan yang lebih baik, perkawinan yang lebih baik dan lain sebagainya. Akan tetapi di negara berkembang, kemiskinan masih menjadi salah satu faktor yang menghambat rumah tangga miskin untuk mengakses pendidikan bagi anak-anaknya. Oleh karena itu dibutuhkan peran pemerintah untuk menyediakan pendidikan yang mudah diakses oleh rumah tangga miskin. Salah satu hambatan bagi pemerintah untuk menyediakan jasa pendidikan yang mudah diakses oleh rumah tangga ialah masalah biaya penyediaannya. Oleh karena itu di dalam penelitian ini akan dilakukan simulasi pengalihan subsidi bahan bakar minyak untuk penyediaan jasa pendidikan dengan menggunakan alat analisis SUBSIM. Berdasarkan skenario yang dibangun ternyata diketahui bahwa yang paling menikmati penurunan harga jasa pendidikan justru rumah tangga miskin yang memiliki pengeluaran konsumsi perkapita 20\% tertinggi, karena rumah tangga tersebut memiliki pengeluaran untuk pendidikan yang lebih tinggi dibandingkan dengan rumah tangga lainnya. Oleh karena itu yang menjadi tantangan pemerintah adalah bagaimana mendorong rumah tangga miskin untuk mau menyekolahkan anak-anaknya lebih tinggi.
\end{abstract}

\begin{abstract}
Education is one of the most important aspects in a person's life because it will affect his life for the better in the future. They will have the opportunity to get a better job, better marriage and so on. However, in developing countries, poverty is still one of the factors that prevent poor households from accessing education for their children. Therefore, it is necessary for the government to provide accessible education by poor households. One obstacle for governments to provide educational services is the cost of providing them. Therefore, in this research will be simulated the transfer of fuel subsidy for the provision of education services using the SUBSIM analysis tool. Based on the scenario built, it was found that the most enjoying the price of education services decline was the poor households with the highest 20\% per capita consumption expenditure. They had higher education expenditure compared to other households. Therefore, the challenge of the government is how to encourage poor households to send their children for higher education
\end{abstract}

\section{LATAR BELAKANG}

Pendidikan merupakan salah satu aspek terpenting dalam kehidupan seseorang karena akan mempengaruhi kehidupannya ke arah yang lebih baik di masa yang akan datang. Mereka akan memiliki kesempatan untuk mendapatkan pekerjaan yang lebih baik, perkawinan yang lebih baik dan lain sebagainya (Behrman, Rosenzweig, 
\& Taubman, 1994). Akan tetapi, dalam konteks negara berkembang, kemiskinan masih menjadi halangan bagi orang tua di rumah tangga miskin untuk menyekolahkan anak-anaknya (Suryadarma \& Suryahadi, 2010). Hal ini akan menyebabkan anak-anak di rumah tangga miskin akan mewarisi kemiskinan orang tuanya, sehingga dibutuhkan peran pemerintah untuk memutus lingkaran setan kemiskinan ini.

Salah satu hal yang dapat dilakukan pemerintah untuk mengatasi hal tersebut adalah dengan menyediakan sarana dan prasarana pendidikan yang mudah diakses oleh rumah tangga miskin. Akan tetapi untuk menyediakan sarana dan prasarana pendidikan tersebut dibutuhkan biaya yang cukup besar sehingga dapat membebani keuangan negara. Oleh karena itu dibutuhkan kebijakan anggaran agar penyediaan sarana dan prasarana pendidikan tersebut dapat dilakukan. Kebijakan anggaran yang dapat dilakukan ialah dengan melakukan kebijakan pengalihan subsidi bahan bakar minyak (BBM) untuk pendidikan anak-anak di rumah tangga miskin.

Pemerintah Indonesia, sama seperti pemerintahan lain di dunia, memberikan subsidi yang cukup besar untuk BBM. Hal ini dikarenakan dalam 10 tahun terakhir, harga minyak dunia mengalami peningkatan yang cukup tinggi, dari US\$25 pada bulan Januari 2003 menjadi US\$104.63 pada bulan Juli 2014. Hal ini berarti dalam kurun waktu 11 tahun lebih, harga minyak dunia telah meningkat lebih dari 4 kali lipat.

Peningkatan harga minyak dunia ini berimplikasi pada meningkatnya pula harga BBM di pasar dunia, karena BBM merupakan salah satu hasil turunan dari minyak bumi. Selain kecenderungan harga minyak dunia yang semakin meningkat, beratnya beban subsidi terhadap Anggaran Pendapatan dan Belanja Negara (APBN) juga diperparah oleh depresiasi nilai tukar rupiah terhadap mata uang dollar Amerika Serikat. Dengan demikian kebijakan pemberian subsidi BBM yang dilakukan oleh pemerintah, akan semakin memberatkan perekonomian di masa yang akan datang.

Mulai tahun 2004, Indonesia telah menjadi negara pengimpor minyak, sehingga isu beban subsidi energi yang begitu besar terhadap belanja pemerintah mendapatkan perhatian yang lebih serius. Pengurangan beban subsidi BBM ini selalu menjadi agenda utama dalam penyusunan RAPBN.
Akan tetapi karena adanya penolakan yang kuat, baik dari masyarakat maupun DPR, maka reformasi subsidi BBM ini berjalan sangat lambat. Argumen utama yang selalu diutarakan oleh para penolak reformasi subsidi BBM ini ialah bahwa pengurangan subsidi BBM akan menyebabkan peningkatan harga BBM, di mana peningkatan harga tersebut akan memicu peningkatan hargaharga barang lainnya, yang akan mengurangi daya beli masyarakat dan memperburuk kemiskinan yang ada (Yusuf \& Resosudarmo, 2008).

Pada dasarnya, tujuan utama dari kebijakan pemberian subsidi BBM ini ialah untuk melindungi pendapatan riil rumah tangga, khususnya rumah tangga miskin (Coady \& Newhouse, 2006). Akan tetapi kebijakan ini memiliki konsekuensi yang cukup memberatkan bagi keuangan pemerintah, karena dengan semakin meningkatnya subsidi, maka kemampuan pemerintah untuk menyediakan layanan publik lainnya akan semakin terbatas.

Hal ini semakin diperparah oleh skema kebijakan pemberian subsidi BBM di Indonesia, yang tidak membatasi pembelian BBM bersubsidi oleh rumah tangga. Dengan demikian, baik rumah tangga miskin maupun rumah tangga kaya, memiliki kesempatan yang sama untuk membeli BBM bersubsidi. Kementerian Koordinator Perekonomian Indonesia memperkirakan bahwa 40 persen rumah tangga berpenghasilan tertinggi menikmati 70 persen subsidi yang diberikan oleh pemerintah, sedangkan 40 persen rumah tangga berpenghasilan terendah hanya menikmati 15 persen dari subsidi tersebut (Jacobs, et al., 2008). Dengan demikian, sebagian besar manfaat dari subsidi tersebut dinikmati oleh rumah tangga yang tidak miskin, yang seharusnya tidak perlu lagi dibantu oleh pemerintah dengan kebijakan subsidi tersebut.

Selain memberatkan keuangan pemerintah dan penentuan target rumah tangga yang buruk, harga yang rendah dari BBM bersubsidi menyebabkan terjadinya pemborosan penggunaan BBM bersubsidi oleh rumah tangga, karena tidak ada insentif bagi rumah tangga untuk melakukan penghematan BBM yang digunakan, agar dapat meredam dampak buruk dari peningkatan harga minyak di pasar dunia. Selain itu, harga yang rendah tersebut juga akan mengaburkan sinyal dari harga sehingga akan mendistorsi keputusan investasi untuk pengembangan teknologi produksi yang 
lebih baik (Mourougane, 2010). Akan tetapi untuk kasus Indonesia, isu subsidi BBM memberatkan keuangan negara lebih dominan dibandingkan isu subsidi BBM untuk mendorong penggunaan energi alternatif.

Dengan adanya pro kontra dari reformasi subsidi BBM yang akan dilakukan oleh pemerintah, maka perlu dilakukan kajian mengenai kebijakan pemberian subsidi BBM ini. Untuk melakukan simulasi kebijakan pengalihan subsidi BBM terhadap pendidikan anak-anak di rumah tangga miskin, penelitian ini akan menggunakan pendekatan keseimbangan umum yang dilakukan oleh Bank Dunia. Adapun alat analisis yang digunakan untuk memperlihatkan keseimbangan umum tersebut adalah SUBSIM yang merupakan produk dari Bank Dunia dan didesain untuk mengarahkan pembuat kebijakan dalam pengambilan keputusan mengenai reformasi subsidi (Verme \& Araar, 2016).

Untuk mengaplikasikan model keseimbangan tersebut, dibutuhkan data Survey Sosial Ekonomi Nasional (SUSENAS) dan Input Output dengan tahun yang sama untuk memastikan bahwa rumah tangga menghadapi tingkat harga yang sama dengan tingkat harga yang digunakan untuk membentuk data Input Output. Model Input Output sendiri dipandang sebagai model keseimbangan umum sederhana yang dapat menangkap sebagian besar dampak kesejahteraan bagi perekonomian tanpa perlu asumsi respon perilaku tertentu dari seluruh agen dan seluruh pasar seperti yang dibutuhkan dalam membangun Model Computable General Equilibrium (CGE). Oleh karena itu, Model CGE dan Model Input Output diperkirakan akan mencapai hasil yang mirip apabila terjadi guncangan harga (price shocks) (Verme \& Araar, 2016).

\section{PERMASALAHAN PENELITIAN}

Rumah tangga miskin memiliki keterbatasan dalam mengakses pendidikan bagi anakanaknya, sehingga anak-anak di rumah tangga miskin cenderung memiliki akumulasi sumber daya manusia yang lebih rendah dibandingkan dengan anak-anak di rumah tangga tidak miskin. Rendahnya akumulasi sumber daya manusia yang dimiliki oleh anak-anak yang berasal dari rumah tangga miskin, akan menyebabkan mereka sulit bersaing di dunia kerja, sehingga mereka cenderung untuk mewarisi kemiskinan yang dialami oleh orang tua mereka. Hal tersebut juga dapat berlanjut pada anak-anak yang kelak akan mereka miliki.

Untuk memutus lingkaran setan kemiskinan tersebut, diperlukan peran pemerintah untuk menyediakan akses pendidikan yang baik bagi rumah tangga miskin, sehingga anak-anak di rumah tangga miskin dapat memiliki sumber daya manusia yang lebih baik. Akan tetapi pemerintah memiliki keterbatasan sumber daya untuk menyediakan akses pendidikan tersebut, sehingga perlu dilakukan kebijakan pengalihan anggaran agar tidak membebani keuangan pemerintah. Salah satu kebijakan pengalihan anggaran yang mungkin dilakukan pemerintah adalah dengan mengalihkan subsidi BBM untuk menyediakan akses pendidikan bagi anak-anak di rumah tangga miskin. Akan tetapi kebijakan pengalihan anggaran subsidi BBM tersebut dapat kontraproduktif apabila kebijakan tersebut malahan memperburuk kemiskinan yang ada. Oleh karena itu perlu dilakukan kajian mendalam mengenai kebijakan pengalihan subsidi BBM tersebut dan salah satu kajian yang dapat dilakukan ialah dengan melakukan simulasi kebijakan pengalihan anggaran subsidi BBM tersebut.

\section{TUJUAN PENELITIAN}

Dari pembahasan di atas maka dapat disimpulkan bahwa tujuan penelitian yang ingin dicapai ialah mengetahui bagaimanakah dampak kebijakan pengalihan subsidi BBM untuk pendidikan anak-anak di rumah tangga miskin berpengaruh terhadap tingkat kesejahteraan rumah tangga miskin tersebut.

\section{PENELITIAN SEBELUMNYA}

Kebijakan pemberian subsidi BBM merupakan kebijakan yang biasa dilakukan di negara berkembang. Hal ini dilakukan dengan tujuan untuk meningkatkan kesejahteraan masyarakat, khususnya rumah tangga miskin. Selain itu, kebijakan tersebut juga ditujukan untuk meningkatkan pertumbuhan ekonomi.

Dari pembahasan sebelumnya, diketahui bahwa lama kelamaan kebijakan pemberian subsidi BBM tersebut akan semakin membebani keuangan pemerintah. Selain alasan tersebut, kebijakan pemberian subsidi BBM juga menyebabkan terjadi 
pemborosan penggunaan BBM oleh rumah tangga dan juga mengurangi insentif untuk perkembangan teknologi produksi yang lebih efisien energi. Oleh karena itu diperlukan upaya untuk melakukan reformasi pemberian subsidi BBM tersebut agar manfaat dari pemberian subsidi itu dapat tercapai, dengan menghilangkan ekses negatif dari pemberian subsidi tersebut.

Untuk mengkaji kebijakan reformasi subsidi BBM tersebut, telah banyak dilakukan penelitian untuk melihat bagaimanakah dampak dari kebijakan tersebut terhadap kesejahteraan rumah tangga. Coady dan Newhouse, dengan menggunakan data Ghana, melakukan evaluasi mengenai dampak peningkatan harga BBM terhadap Keuangan Pemerintah dan Biaya Sosial di masyarakat. Mereka menemukan bahwa dengan adanya peningkatan harga BBM di Ghana, akan menurunkan 9,1 persen pendapatan riil dari rumah tangga termiskin. Akan tetapi dengan mempertahankan harga BBM yang rendah pun, merupakan pendekatan yang kurang efisien dalam melindungi rumah tangga miskin tersebut, karena adanya kebocoran dari manfaat subsidi ke rumah tangga yang tidak miskin. Dengan demikian program dengan target yang lebih baik akan dapat mengurangi kerugian tersebut. Simulasi tersebut dilakukan tanpa melakukan kompensasi terhadap rumah tangga, akibat adanya peningkatan harga BBM tersebut.

Untuk kasus Indonesia, Widodo dan kawankawan (2012), dengan menggunakan data SNSE Indonesia, melakukan simulasi terhadap kebijakan penghapusan subsidi BBM. Mereka menemukan bahwa kebijakan tersebut mempengaruhi variabelvariabel ekonomi seperti output, PDB, dan pendapatan faktor produksi. Selain itu, simulasi tersebut juga mempengaruhi distribusi pendapatan rumah tangga, pemerintah dan perusahaan. Dari hasil tersebut, mereka berkesimpulan bahwa kebijakan penghapusan subsidi BBM akan berdampak terhadap perekonomian Indonesia, baik melalui sisi permintaan maupun sisi penawaran. Oleh karena itu diperlukan kebijakan penghapusan subsidi BBM yang bersifat gradual dalam jangka panjang, agar dampak negatif dari penghapusan subsidi BBM tersebut dapat diminimalisir (Widodo, Sahadewo, Setiastuti, \& Chaerriyah, 2012).

Yusuf dan Resosudarmo (2008), dengan menggunakan model Computable General
Equilibrium (CGE) menganalisis dampak dari peningkatan harga BBM bersubsidi terhadap distribusi pendapatan rumah tangga. Mereka berkesimpulan bahwa kebijakan tersebut akan dapat bersifat progresif apabila hanya menaikkan harga BBM untuk kendaraan saja. Akan tetapi kebijakan tersebut akan dapat meningkatkan ketimpangan pendapatan apabila harga BBM untuk rumah tangga (minyak tanah) juga ikut dinaikkan. Oleh karena itu diperlukan bantuan langsung tunai yang cukup dan efektif bagi rumah tangga miskin untuk mengurangi dampak negatifdari kebijakan tersebut. Bantuan langsung tunai yang sama untuk seluruh rumah tangga akan cenderung mengkompensasi lebih (overcompensate) bagi rumah tangga miskin di pedesaan dan mengkompensasi kurang (undercompensate) bagi rumah tangga miskin di perkotaan (Yusuf \& Resosudarmo, 2008).

Ikhsan dan kawan-kawan (2005), dengan menggunakan model CGE, melakukan simulasi dengan menggunakan data survey rumah tangga, menganalisis dampak dari kebijakan peningkatan harga BBM 2005 terhadap tingkat kemiskinan yang terjadi. Dari hasil simulasi tersebut, diperkirakan bahwa kemiskinan akan meningkat sebesar 0,24 persen, apabila tidak ada kompensasi yang diberikan terhadap rumah tangga. Apabila rumah tangga diberikan kompensasi, maka kemiskinan akan menurun sebesar 2,6 persen. Dari simulasi tersebut juga dihasilkan bahwa kebijakan tersebut akan cenderung untuk mengurangi ketimpangan yang terjadi (Ikhsan, Dartanto, Usman, \& Sulistyo, 2005).

Clements dan kawan-kawan (2003) melakukan simulasi peningkatan harga BBM di Indonesia sebesar 25 persen dengan menggunakan model CGE.Darisimulasitersebut, didapatkan kesimpulan bahwa tingkat konsumsi riil rumah tangga akan menurun berkisar antara 2,1 persen sampai dengan 2,7 persen, di mana rumah tangga perkotaan dan yang berpendapatan tinggi mengalami penurunan konsumsi yang terbesar. Hasil ini mengindikasikan bahwa kebijakan peningkatan harga BBM tersebut akan mengurangi kesenjangan yang terjadi antara rumah tangga berpendapatan rendah dan tinggi (Clements, Gupta, \& Jung, 2003). Akan tetapi yang perlu menjadi catatan di sini ialah bahwa rumah tangga berpendapatan rendah pun akan terkena dampak dari kebijakan tersebut, sehingga perlu dilindungi dengan kebijakan kompensasi yang 
baik sehingga kesejahteraan mereka tidak semakin menurun.

Dari beberapa penelitian di atas mengenai kasus Indonesia, pada dasarnya dapat ditarik kesimpulan bahwa kebijakan pengurangan subsidi BBM akan berdampak terhadap seluruh rumah tangga, baik rumah tangga miskin maupun rumah tangga tidak miskin. Akan tetapi karena tujuan dari subsidi ini untuk melindungi pendapatan riil rumah tangga, khususnya rumah tangga miskin, maka kebijakan penghapusan subsidi BBM tersebut harus diikuti dengan kebijakan kompensasi yang baik, sehingga kebijakan tersebut dapat memperbaiki distribusi pendapatan masyarakat.

\section{DATA DAN METODE PENELITIAN}

Pada dasarnya, tujuan utama dari kebijakan pemberian subsidi BBM ini ialah untuk melindungi pendapatan riil rumah tangga, khususnya rumah tangga miskin (Coady \& Newhouse, 2006). Akan tetapi karena adanya skema kebijakan pemberian subsidi BBM di Indonesia, yang tidak membatasi pembelian BBM bersubsidi oleh rumah tangga, maka rumah tangga miskin maupun rumah tangga tidak miskin, memiliki kesempatan yang sama untuk membeli BBM bersubsidi. Oleh karena itu dirasakan skema kebijakan pemberian subsidi BBM tersebut kurang memenuhi rasa keadilan di masyarakat.

Di dalam penelitian ini akan dilakukan simulasi kebijakan pengalihan subsidi BBM untuk pendidikan anak-anak di rumah tangga miskin terhadap tingkat kesejahteraan rumah tangga miskin tersebut. Hal ini dilakukan agar rumah tangga miskin lebih mampu untuk mengakses pendidikan bagi anak-anak mereka, sehingga diharapkan anak-anak tersebut memiliki sumberdaya manusia yang lebih baik dibandingkan orang tua mereka. Dengan demikian, mereka tidak mewarisi kemiskinan yang dialami oleh orang tuanya.

Untuk melihat bagaimanakah dampak dari kebijakan pengalihan subsidi BBM tersebut, akan dilakukan simulasi dengan menggunakan model keseimbangan umum dengan menggunakan alat analisis SUBSIM yang dibangun oleh Bank Dunia. Simulasi yang dilakukan dengan menggunakan alat SUBSIM membutuhkan data SUSENAS dan data Input Output pada tahun yang sama untuk memastikan bahwa rumah tangga menghadapi harga yang sama dengan harga untuk membangun data Input Output. Dengan demikian keseimbangan umum di dalam penelitian ini dihasilkan dari model Input Output yang merupakan model keseimbangan umum sederhana.

Model Input Output mampu menangkap sebagian besar dampak kesejahteraan bagi perekonomian apabila terjadi perubahan harga (price shock), tanpa memerlukan asumsi respon perilaku tertentu dari seluruh agen dan seluruh pasar. Dengan demikian dari sisi kompleksitas model, Model Input Output jauh lebih sederhana daripada Model Computable General Equilibrium (CGE), walaupun diperkirakan kedua model tersebut akan mencapai hasil yang mirip (Verme \& Araar, 2016).

Kelemahan paling mendasar dari Model CGE adalah ketergantungan model tersebut pada konstruksi teoritis dan asumsi yang digunakan (Rennings, 2003). Kita harus berhati-hati dalam melakukan interpretasi hasil karena kesimpulan yang dihasilkan sangat tergantung pada asumsi yang digunakan. Selain itu, Model CGE kurang cocok untuk keperluan peramalan (forecasting), karena meskipun model tersebut memiliki kelebihan dalam konsistensi internal (melalui hubungan teoritis) akan tetapi model tersebut sering memiliki kekurangan konsistensi eksternal (dengan data dan perilaku riil dari perekonomian) (Rennings, 2003). Oleh karena itu, di dalam penelitian ini akan digunakan model keseimbangan umum yang dapat mengakomodasi data SUSENAS untuk melihat dampak kebijakan pengalihan subsidi BBM tersebut terhadap tingkat kesejahteraan di level rumah tangga miskin.

Alat analisis SUBSIM mampu untuk mengakomodasi data SUSENAS dalam melihat keseimbangan umum yang terjadi karena adanya kebijakan pengalihan subsidi BBM tersebut. Sebelum mengaplikasikan model keseimbangan umum tersebut, dibutuhkan data pengeluaran konsumsi makanan rumah tangga miskin untuk memastikan besaran kompensasi yang diberikan ke rumah tangga miskin. Besaran kompensasi tersebut digunakan untuk mempertahankan pola konsumsi makanan mereka, sehingga mereka terhindar dari peningkatan harga makanan yang mereka konsumsi. Oleh karena keterbatasan alat SUBSIM di dalam mensimulasikan pengalihan subsidi BBM tersebut, maka tidak seluruh komoditas makanan rumah tangga miskin akan 
dimasukkan dalam besaran kompensasi tersebut. Oleh karena itu, komoditas yang dipilih adalah 5 komoditas dengan pengeluaran konsumsi terbesar yang dilakukan oleh rumah tangga miskin.

Setelah didapatkan 5 komoditas dengan pengeluaran konsumsi terbesar yang dilakukan oleh rumah tangga miskin, langkah berikutnya ialah melakukan estimasi elastisitas untuk ke 5 komoditas tersebut. Estimasi elastisitas dilakukan persamaan permintaan sederhana sebagai berikut (Araar \& Verme, 2012).

$\ln Q_{h}=\alpha+\beta \ln e_{h}+\gamma \ln p_{1, h}+\epsilon_{h}$

Di mana $\beta$ adalah elastisitas pendapatan dan $\gamma$ adalah elastisitas harga. Untuk menghilangkan heterogenitas daerah yang mungkin timbul dari perbedaan wilayah di mana rumah tangga tersebut berada, maka penghitungan akan dilakukan dengan menggunakan metode fixed effect blok sensus. Dengan demikian diasumsikan bahwa besaran elastisitas permintaan suatu komoditas untuk seluruh rumah tangga adalah sama.

Dengan demikian akan dilihat bagaimanakah dampak dari penghapusan subsidi BBM terhadap tingkat pengeluaran rumah tangga miskin terhadap ke 5 komoditas tersebut. Selain ke 5 komoditas tersebut, pengeluaran rumah tangga miskin untuk BBM juga dimasukkan dalam penghitungan karena simulasi dilakukan dengan menghilangkan subsidi BBM yang dinikmati oleh rumah tangga. Akan tetapi karena seluruh rumah tangga menghadapi tingkat harga yang sama, maka nilai elastisitas harga untuk BBM tidak dapat dilakukan. Oleh karena itu, di dalam penelitian ini diasumsikan bahwa nilai elatisitas harga BBM adalah sebesar -0,2 (Dahl, 1993).

Berdasarkan hasil penelusuran yang telah dilakukan, diketahui bahwa besarnya subsidi BBM yang dikeluarkan oleh pemerintah untuk konsumsi BBM rumah tangga adalah sebesar 68,7 triliun rupiah dengan perkiraan konsumsi BBM sebesar 36.505 ribu kiloliter. Dengan demikian diperkirakan bahwa besaran subsidi BBM yang dinikmati rumah tangga adalah sebesar Rp. 1.881,93/liter atau 29,48 persen dari perkiraan harga BBM sebenarnya. Oleh karena itu, di dalam penelitian besarnya peningkatan harga yang dilakukan ialah sebesar 29,48 persen, atau penghapusan total subsidi seluruhnya.
Untuk melihat bagaimanakah dampak dari pengalihan subsidi BBM tersebut untuk pendidikan anak-anak di rumah tangga miskin, di dalam penelitian ini akan diasumsikan bahwa pengalihan subsidi BBM tersebut akan menurunkan harga dari jasa pendidikan pemerintah sebesar 5 persen dan 10 persen. Oleh karena itu, di dalam penelitian ini akan dilakukan simulasi dengan peningkatan harga BBM sebesar 29,48 persen dan penurunan harga jasa pendidikan pemerintah sebesar 5 persen dan 10 persen.

\section{ANALIS HASIL}

Berdasarkan hasil penghitungan yang telah dilakukan, dengan adanya peningkatan harga BBM sebesar 29,48 persen dan penurunan harga jasa pendidikan pemerintah sebesar 5 persen dan 10 persen, akan mendorong peningkatan harga komoditas lainnya antara 0,08 persen sampai dengan 0,57 persen. Peningkatan harga tertinggi dialami oleh komoditas ikan segar yaitu sebesar 0,57 persen dan peningkatan harga terendah adalah pada komoditas beras yaitu sebesar 0,08 persen.

Peningkatan harga beras yang rendah ini mudah dipahami, karena beras merupakan salah satu bahan kebutuhan pokok masyarakat Indonesia dan mendapatkan perhatian yang cukup serius oleh pemerintah dalam pemantauan harganya. Hal ini dikarenakan beras memiliki bobot terbesar dalam penghitungan inflasi. Untuk lebih jelasnya mengenai kenaikan harga akibat kebijakan pengalihan subsidi BBM tersebut dapat dilihat pada tabel 2.4-1.

Tabel 2.4 1.Harga-harga Komoditas Terpilih

\begin{tabular}{lcc} 
& price & price \\
\hline Beras & 1.000000 & 1.000825 \\
\hline Makanan Jadi & 1.000000 & 1.002985 \\
\hline Rokok & 1.000000 & 1.003730 \\
\hline Ikan segar & 1.000000 & 1.005657 \\
\hline Sayuran & 1.000000 & 1.001013 \\
\hline BBM & 1.000000 & 1.294800 \\
\hline Pendidikan & 1.000000 & 0.950000 \\
\hline
\end{tabular}

Sumber: Susenas 2010, diolah

Akan tetapi apabila dilihat dari total pengeluaran rumah tangga miskin untuk ke 5 komoditas makanan tersebut, beras merupakan komoditas dengan pengeluaran terbesar. Hal ini juga terlihat dalam struktur pengeluaran konsumsi rumah 
Pengaruh Kebijakan Pengalihan Subsidi Bahan Bakar Minyak (BBM)... [Adji Pratikto]

Tabel 2.4 2. Total Pengeluaran Konsumsi Perkapita (Rp.)

\begin{tabular}{lcccccccc}
\hline \hline & \multirow{2}{*}{ Beras } & $\begin{array}{c}\text { Makanan } \\
\text { Jadi }\end{array}$ & \multicolumn{1}{c}{ Rokok } & Ikan segar & \multicolumn{1}{c}{ Sayuran } & \multirow{2}{*}{ BBM } & Pendidikan & \multirow{2}{*}{ Total } \\
\hline Quintile 1 & $252,947.69$ & $55,256.56$ & $76,395.31$ & $63,892.57$ & $66,049.98$ & $43,059.82$ & $67,063.90$ & $624,665.81$ \\
Quintile 2 & $258,732.92$ & $90,744.73$ & $117,044.95$ & $92,627.94$ & $83,605.52$ & $71,431.44$ & $91,471.85$ & $805,659.38$ \\
Quintile 3 & $253,643.08$ & $123,084.42$ & $149,814.36$ & $116,956.10$ & $96,844.77$ & $101,764.60$ & $122,286.15$ & $964,393.50$ \\
Quintile 4 & $244,354.41$ & $175,592.39$ & $183,693.58$ & $145,613.47$ & $110,866.59$ & $143,531.70$ & $180,538.56$ & $1,184,190.63$ \\
Quintile 5 & $230,105.36$ & $350,516.63$ & $216,514.30$ & $193,377.08$ & $128,938.28$ & $280,590.00$ & $397,994.88$ & $1,798,036.50$ \\
\hline Total & $247,956.67$ & $159,038.31$ & $148,691.91$ & $122,492.99$ & $97,260.77$ & $128,075.00$ & $171,870.52$ & $1,075,386.25$ \\
\hline \hline
\end{tabular}

tangga untuk komoditas tersebut. Oleh karena itu dapat disimpulkan bahwa rumah tangga miskin memiliki ketergantungan yang cukup tinggi akan konsumsi beras.

Apabila populasi rumah tangga miskin dibagi ke dalam 5 kategori berdasarkan pengeluaran konsumsi perkapita (Quintile), maka populasi yang berada pada quintile 2 mengalami peningkatan total pengeluaran konsumsi beras perkapita terbesar. Dengan demikian dapat disimpulkan bahwa ketergantungan rumah tangga yang berada pada quintile 2 terhadap konsumsi beras, lebih tinggi bila dibandingkan dengan rumah tangga lainnya.

Untuk komoditas makanan lainnya menunjukkan kecenderungan bahwa rumah tangga yang berada pada kelompok quintile yang lebih besar (berarti masuk dalam kelompok dengan pengeluaran konsumsi rumah tangga perkapita lebih tinggi), akan memiliki pengeluaran konsumsi perkapita yang lebih besar untuk komoditas makanan tersebut. Untuk lebih jelasnya dapat dilihat pada tabel 2.4-2.

Apabila dilihat dari dampak pengalihan subsidi BBM tersebut terhadap kesejahteraan rumah tangga miskin, terdapat perbedaan yang cukup signifikan antara penurunan harga jasa pendidikan pemerintah dengan skenario penurunan 5 persen dan 10 persen. Dengan adanya penurunan jasa pendidikan pemerintah sebesar 5 persen, masih menyebabkan penurunan tingkat kesejahteraan seluruh rumah tangga miskin sebesar 4,78 persen. Hal ini berarti seluruh rumah tangga miskin masih mengalami penurunan tingkat kesejahteraan dengan adanya kebijakan pengalihan subsidi BBM tersebut, walaupun telah dikompensasi dengan peningkatan subsidi untuk pendidikan anak-anak mereka. Hal ini terlihat pada tabel 2.4-3.

Tabel 2.4 3.Dampak Terhadap Tingkat Kesejahteraan Rumah Tangga Miskin (dalam persentase)

\begin{tabular}{lll}
\hline & $5 \%$ & $10 \%$ \\
\hline Quintile 1 & -3.96 & -2.00 \\
\hline Quintile 2 & -4.80 & -2.85 \\
\hline Quintile 3 & -5.22 & -3.16 \\
\hline Quintile 4 & -5.25 & -2.35 \\
\hline Quintile 5 & -4.53 & 49.30 \\
\hline Total & -4.78 & 18.74 \\
\hline
\end{tabular}

Sumber: Susenas 2010, diolah

Akan tetapi hal yang berbeda terjadi manakala penurunan harga jasa pendidikan pemerintah adalah sebesar 10 persen. Dengan adanya penurunan harga jasa pendidikan ini, secara umum tingkat kesejahteraan rumah tangga miskin mengalami peningkatan yaitu sebesar 18,74 persen. Hal ini berarti bagi rumah tangga miskin penurunan harga jasa pendidikan pemerintah sebesar 10 persen cukup membantu mereka dalam mengkompensasi peningkatan harga BBM yang mereka alami.

Apabila dilihat per kategori pengeluaran konsumsi rumah tangga perkapita, dampak terbesar dari adanya penurunan harga jasa pendidikan pemerintah sebesar 10 persen ini dinikmati oleh rumah tangga miskin yang berada pada quintile 5. Hal ini berarti rumah tangga miskin tersebut memiliki tingkat pengeluaran untuk biaya pendidikan yang tertinggi bila dibandingkan dengan rumah tangga lainnya. Oleh karena itu, dengan adanya kompensasi akibat penghapusan subsidi BBM, mereka akan menikmati kompensasi yang terbesar dibandingkan dengan kategori rumah tangga lainnya.

Dengan demikian dapat disimpulkan bahwa orang tua di rumah tangga tersebut memiliki 
kesadaran yang cukup tinggi untuk menyekolahkan anak-anaknya, sehingga pada saat pemerintah mengalihkan subsidi BBM untuk pendidikan anak-anak di rumah tangga miskin, maka mereka menikmati kompensasi terbesar.

Apabila dibandingkan dengan rumah tangga miskin yang berada pada quintile lainnya, ternyata kompensasi untuk penghapusan subsidi BBM tersebut masih menyebabkan penurunan tingkat kesejahteraan rumah tangga miskin tersebut. Oleh karena itu, dapat disimpulkan bahwa kompensasi tersebut belum dapat menghilangkan dampak negatif yang ditimbulkan dari penghapusan subsidi BBM terhadap tingkat kesejahteraan mereka.

Oleh karena itu dapat disimpulkan bahwa kompensasi terhadap harga jasa pendidikan pemerintah yang dilakukan terkait dengan kebijakan pengalihan subsidi BBM tidak dinikmati oleh rumah tangga miskin secara keseluruhan, khususnya rumah tangga miskin dengan pengeluaran konsumsi perkapita 80 persen terendah. Hal ini terjadi karena rendahnya pengeluaran rumah tangga miskin tersebut untuk biaya pendidikan, sehingga ketika terjadi penurunan harga jasa pendidikan, rumah tangga miskin tersebut tidak menikmati peningkatan kesejahteraan yang cukup berarti. Oleh karena itu perlu dipikirkan kebijakan pengalihan subsidi BBM yang lebih tepat sasaran agar seluruh rumah tangga miskin dapat menikmati kompensasi tersebut.

Oleh karena yang menikmati kompensasi terbesar dari kebijakan pengalihan subsidi BBM tersebut adalah rumah tangga miskin dengan pengeluaran konsumsi perkapita 20 persen terbesar, maka hal tersebut menyebabkan ketimpangan yang terjadi juga semakin meningkat. Berdasarkan hasil penghitungan yang telah dilakukan, dengan adanya kebijakan pengalihan subsidi BBM tersebut akan menyebabkan ketimpangan di antara rumah tangga miskin meningkat sebesar 13,79 persen. Hal ini sejalan dengan penelitian yang dilakukan oleh Yusuf dan Resosudarmo (2008), di mana mereka menganalisis dampak dari peningkatan harga BBM bersubsidi terhadap distribusi pendapatan rumah tangga dan mendapatkan kesimpulan bahwa kebijakan tersebut akan cenderung meningkatkan ketimpangan pendapatan (Yusuf \& Resosudarmo, 2008).

Akan tetapi hal berbeda dihasilkan dari penelitian Ikhsan et.al. (2005) di mana kebijakan pengalihan subsidi BBM dengan pemberian kompensasi terhadap rumah tangga miskin, akan menurunkan tingkat kemiskinan dan cenderung untuk mengurangi ketimpangan yang terjadi (Ikhsan, et al., 2005). Begitu juga penelitian oleh Clements et.al (2003) yang juga melakukan simulasi peningkatan harga BBM dan mendapatkan kesimpulan bahwa kebijakan peningkatan harga BBM tersebut akan mengurangi kesenjangan antara rumah tangga berpendapatan tinggi dan rendah (Clements, et al., 2003).

Selain terhadap ketimpangan, kebijakan pengalihan subsidi BBM tersebutjuga menyebabkan tingkat kemiskinan meningkat sebesar 6 persen. Hal ini sejalan dengan penelitian Coady dan Newhouse, yang menggunakan data Ghana untuk melihat dampak dari peningkatan harga BBM di Ghana dan mendapatkan kesimpulan bahwa hal tersebut akan menurunkan tingkat pendapataan riil dari rumah tangga termiskin. Oleh karena itu, kebijakan peningkatan harga BBM tersebut akan memperparah kemiskinan yang terjadi (Coady \& Newhouse, 2006).

Akan tetapi mereka juga berkesimpulan bahwa kebijakan untuk mempertahankan harga BBM yang rendah pun merupakan kebijakan yang kurang baik dalam melindungi rumah tangga miskin tersebut. Hal ini dikarenakan adanya kebocoran dari manfaat subsidi ke rumah tangga yang tidak miskin. Dengan demikian, mereka menyarankan agar kebijakan pengalihan subsidi BBM dilakukan dengan target yang lebih baik sehingga dapat meminimalisir kebocoran yang terjadi.

Untuk lebih jelasnya mengenai dampak dari kebijakan pengalihan subsidi BBM terhadap tingkat kesejahteraan rumah tangga, tingkat kemiskinan dan tingkat ketimpangan yang terjadi, maka akan disajikan tabel 2.4-4.

Tabel 2.4 4.Dampak Kebijakan Pengalihan Subsidi BBM

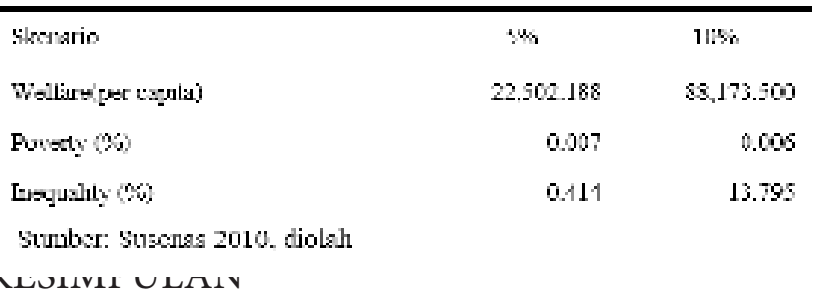

Berdasarkan hasil pembahasan di atas, terdapat beberapa kesimpulan yang dapat diambil terkait dengan kebijakan pengalihan subsidi BBM untuk pendidikan anak-anak di rumah tangga miskin 
yaitu:

a. Seluruh rumah tangga miskin akan terkena dampak dari peningkatan harga BBM yang terjadi, di mana dampak tersebut akan mengurangi tingkat kesejahteraan rumah tangga miskin terkait dengan kemampuan rumah tangga miskin untuk mengkonsumsi kebutuhan makanannya.

b. Untuk skenario pertama, di mana kebijakan pengalihan subsidi BBM tersebut akan menurunkan harga jasa pendidikan pemerintah sebesar 5 persen, belum dapat untuk mengkompensasi penurunan kesejahteraan yang diakibatkan oleh peningkatan harga BBM. Akan tetapi untuk skenario yang kedua, kebijakan pengalihan subsidi BBM tersebut mampu untuk mengkompensasi penurunan kesejahteraan walaupun hanya untuk rumah tangga miskin dengan pengeluaran konsumsi perkapita 20 persen terbesar saja. Untuk rumah tangga miskin lainnya, kebijakan pengalihan tersebut belum cukup mampu untuk mengkompensasi penurunan kesejahteraan tersebut

c. Selain terhadap tingkat kesejahteraan rumah tangga miskin, kebijakan pengalihan subsidi BBM tersebut juga akan meningkatkan tingkat kemiskinan dan tingkat ketimpangan yang dialami oleh rumah tangga miskin. Hal ini sejalan dengan penelitian yang dilakukan oleh Yusuf dan Resosudarmo (2008).

\section{KETERBATASAN PENELITIAN}

Permasalahan di dalam penelitian ini ialah mengenai bagaimana kebijakan pengalihan subsidi BBM untuk pendidikan anak-anak di rumah tangga miskin, akan berpengaruh terhadap tingkat kesejahteraan di rumah tangga miskin tersebut. Hal ini dikarenakan rumah tangga miskin masih mengalami halangan untuk mengakses tingkat pendidikan tertentu yang diinginkannya.

Pada dasarnya subsidi diberikan oleh pemerintah untuk melindungi tingkat pendapatan riil rumah tangga miskin. Akan tetapi karena keterbatasan dalam skema pemberian subsidi BBM, maka rumah tangga yang tidak miskin pun dapat mengakses subsidi BBM tersebut sehingga diperkirakan kurang memenuhi rasa keadilan masyarakat. Oleh karena itu apabila subsidi BBM tersebut dialihkan untuk pendidikan anak-anak di rumah tangga miskin, apakah akan berpengaruh terhadap tingkat kesejahteraan rumah tangga tersebut.
Untuk mengetahui hal tersebut, dilakukan penghitungan dengan model keseimbangan umum dengan mengasumsikan bahwa kebijakan pengalihan subsidi BBM tersebut diberikan dalam bentuk penurunan harga jasa pendidikan pemerintah. Oleh karena ada keterbatasan dalam mengakses data yang ada, maka tidak ada kepastian mengenai berapa besar penurunan harga jasa pendidikan pemerintah yang terjadi akibat dari kebijakan pengalihan subsidi BBM tersebut. Dengan demikian, di dalam penelitian ini akan dibangun 2 skenario penurunan harga tersebut yaitu penurunan harga sebesar 5 persen dan 10 persen.

\section{DAFTAR RUJUKAN}

Araar, A., \& Verme, P. (2012). Reforming Subsidies: a Tool Kit for Policy Simulations. World Bank Policy Research Working Paper, 6148.

Behrman, J. R., Rosenzweig, M. R., \& Taubman, P. (1994). Endowments and The Allocation of Schooling in the Family and in the Marriage Market: The Twins Experiment. Journal of Political Economy, 102(no. 6), pp. 1131 - 1174.

Clements, B., Gupta, S., \& Jung, H.-S. (2003). Real and Distributive Effects of Petroleum Price Liberalization: The Case of Indonesia. IMF Working Paper

Coady, D., \& Newhouse, D. (Eds.). (2006). Evaluating The Distribution of The Real Income Effects of Increases in Petroleum Product Prices in Ghana. Washington DC: World Bank.

Dahl, C. A. (1993). A Survey of Oil Demand Elasticities for Developing Countries. OPEC Review, 17(winter), pp.399 - 419.

Ikhsan, M., Dartanto, T., Usman, \& Sulistyo, H. (2005). Kajian Dampak Kenaikan Harga BBM 2005 Terhadap Kemiskinan. LPEM Working Paper. Jacobs, B., Coburn, L., Lucas, N., Omote, T., Tromop, R., Linden, N. v. d., et al. (2008). Energy Policy review of Indonesia. Paris: International Energy Agency.

Mourougane, A. (2010). Phasing Out Energy Subsidies in Indonesia. Paris: OECD Publishing. Rennings, K. (2003). Modelling Retrieved 25 July 2017, from www.liaise-kit.eu/ia-method/modelling Suryadarma, D., \& Suryahadi, A. (2010). Determinants of Education Attainment in Developing Countries: Can Higher Skills Compensate for Poverty? RAND working paper. 
Verme, P., \& Araar, A. (2016). SUBSIM: A user Guide.Unpublished manuscript, Washington D.C. Widodo, T., Sahadewo, G. A., Setiastuti, S. U., \& Chaerriyah, M. (2012). Impact of Fuel Subsidy Removal on Government Spending. In Y. Wu., X. Shi \& F. Kimura (Eds.), Cambodia's Electricity Sector in the Context of Regional Electricity Market Integration. Jakarta: ERIA.

Yusuf, A. A., \& Resosudarmo, B. P. (2008). Mitigating Distributional Impact of Fuel Pricing Reform: The Indonesian Experience. ASEAN Economic Bulletin, vol. 25(No. 1), pp.32-47. 